\title{
Texts, Bodies, and the Memory of Bloody Sunday
}

\author{
Lyn Spillman \\ University of Notre Dame \\ Brian Conway \\ National University of Ireland, Maynooth
}

\begin{abstract}
We examine here recent arguments that embodied experience is an important site of collective memory, and related challenges to the standard emphasis on discourse and symbols in collective memory research. We argue that although theories of embodied memory offer new insights, they are limited by (1) an overdrawn distinction between embodied memory and textual memory that neglects the complex relations between the two, (2) an overemphasis on ritual performance at the expense of collective conversation, (3) an oversimplified view of performativity, and (4) an underestimation of the ambiguity in embodied performance. Theories of embodied collective memory should be narrowed and specified with focused comparisons examining the influence of embodied experience in the formation of collective identities, in conflicts over collective memories, and in the persistence and malleability of memories across generations. We illustrate our argument throughout with examples drawn from the collective memory of Bloody Sunday in Northern Ireland in 1972.
\end{abstract}

In what sense, if any, can the body be understood as a site of collective memory? A strong line of theory and research now argues that embodied experience is a fundamental and neglected form of collective memory. However, sociological studies of collective memory have been slow to engage with and assess this argument, even though it is potentially relevant to many of the topics we examine. Can claims about the importance of embodied collective memory sensitize us to examine new angles on the issues of identity, contestation, and malleability that underpin our empirical investigations in social memory studies (Olick and Robbins 1998)? What are the possibilities and limits of these claims?

Until quite recently, sociology "never successfully posed the question of the body as a historical issue" (Turner 1991:8). Although social theory does address the contradiction

Direct all correspondence to Lyn Spillman, Department of Sociology, 810 Flanner Hall, University of Notre Dame, Notre Dame IN 46556; e-mail: Spillman.1@nd.edu.

Symbolic Interaction, Vol. 30, Issue 1, pp. 79-103, ISSN 0195-6086, electronic ISSN 1533-8665. (C) 2007 by the Society for the Study of Symbolic Interaction. All rights reserved. Please direct all requests for permission to photocopy or reproduce article content through the University of California Press's Rights and Permissions website, at http://www.ucpress.edu/journals/rights.htm. 
between civilization and "natural" inclination, its critique is itself grounded in the nature-culture binary. And even interactionist traditions in sociology, Turner suggests, tend to follow Mead's dictum that "we can distinguish very definitely between the self and the body," although Goffman's work could be taken as grounding investigation into the "performance of the self through medium of the socially interpreted body" (Mead 1962:136; Turner 1984:140). Overall, "the legitimate rejection of biological determinism ... entailed ... the exclusion of the body from the sociological imagination" (Turner 1984:31). In contrast, Turner (1991:1-6) elaborates, the "ontological centrality of human embodiment"-and in particular, the phenomenological notion of "the lived body" (Scheper-Hughes and Lock 1987:8-18)—was more influential in the development of anthropological presuppositions. However, recent decades have seen increasing research on the sociology of the body-or, in more expansive claims, "embodied sociology"-grounded in a more sophisticated, process-oriented view of the nature-culture binary. ${ }^{1}$

But attempts to apply theories of embodiment to accounts of collective memory face particular challenges beyond sociology's general theoretical presuppositions about the nature-culture binary, because of qualities intrinsic to social memory itself. We think of collective memories as extended in time, or space, or both. ${ }^{2}$ We also think of such extensions as accomplished symbolically, if not textually. So, on the face of it, phenomenologically grounded accounts of bodily memory seem to offer comparatively poor conceptual resources for understanding the persistence of meanings in history, and their extension in space, compared with accounts relying on more purely cultural or discursive theories. Two related features of collective memory exacerbate this puzzle. There have been fundamental long-term changes in memory's means and mode of production - changes indexed in the oppositions between orality and literacy, face-to-face and imagined community, tradition and organized (often state-generated) construction-perhaps, "memory" and "history" (Olick and Robbins 1998:112-15). These tectonic shifts seem to reduce the potential importance of bodies as sites-or "techne" - of collective memory: as memory is made in new ways, for instance in "media ritual events" (Dayan and Katz 1992), it seems their relative significance could only decline further. Finally, text and representation are the primary modes of access to our object for students of collective memory, even where we are pushing, theoretically, to get beyond an understanding in terms of static textual structure to attend to memory as a process, to the variant reception of textual memory, to the pragmatic moment. Even where we examine the performative, as in studies of ritualized collective memory, we mostly read rituals as texts. So the issue of embodiment poses an important but neglected set of theoretical issues for sociologists concerned with collective memory.

Our primary aim here is to introduce, explore, and assess the case that has been made for the significance of embodied memory. To focus our theoretical discussion, though, we draw on the memory of "Bloody Sunday" in Northern Ireland. On January 30,1972, in a predominantly Catholic area of Derry, thirteen people were killed and fourteen injured by British paratroopers during a peaceful march against the 
policy of internment. The political situation was particularly charged at the time, and the march was one of many: this event, though, became a watershed in the popular memory of "The Troubles." 3 A rapidly conducted official inquiry exonerated the British soldiers involved, though, in the late 1990s, continued popular criticism and new evidence assembled by the Irish government prompted a new inquiry. In contrast to official memory, the contesting popular memory of the event has been richly elaborated in many forms: murals, monuments, archives, museums, books, memoirs, film, posters, and speeches (Conway 2005). Most important here, though, an annual commemorative reenactment of the original march has been organized for over thirty years. We draw on this case not only to illustrate some insights offered by theories of embodied collective memory but also to specify problems they generate.

In the next section, we examine the case that has been made for the importance of embodied collective memory, beginning with some illustrations and summarizing the main theoretical arguments grounding them. Because of their influence, we pay particular attention to Paul Connerton's widely cited arguments for embodied memory in How Societies Remember. We then draw on interviews with participants in the commemorative march for a brief illustration of what this perspective illuminates about the popular memory of Bloody Sunday and what it does not address. Against this background, we analyze Connerton's theoretical argument in more depth and, finally, return to the Bloody Sunday case to detail its limitations.

Overall, we conclude that sociologists should be cautious about arguments that embodied memory is key to collective memory-what we label here "the strong embodiment thesis." This caution seems necessary because advocates of this thesis make too sharp a distinction between incorporated or embodied memory and textual or discursive memory, and ignore the complex relations between them. Although embodied memory can be significant for collective memory when body use in action intensifies the communicative potential for recognition (Frank 1991:89), the strong embodiment thesis offers no way to theorize how bodily memories are always already inscribed, organized, and symbolized.

\section{THE STRONG EMBODIMENT THESIS}

What does it mean to locate social memory in the body? In Lee's (2000) analysis, for instance, the bodies of first-generation Korean migrants in Japan are the site of a sort of ethnic memory in that their tastes in food express their ethnic identification: for instance, eating authentic, spicy kimchi. Lee's understanding of bodily memory is built on Scheper-Hughes and Lock's (1987) model of the "mindful body" and Bourdieu's extension of Mauss's notion of habitus, and she emphasizes how bodily memory "acts as a source of meaning-making and a process of negotiation" (Lee 2000, 206). As one elderly Korean articulates: "My stomach and heart ache together from even just smelling Korean food, because it brings back all the hardship I have suffered in my life. Even if I wanted to forget, I cannot. My body has absorbed the past like a sponge. Forgetting is an impossibility" (p. 216). Of course, food tastes are familiar 
ethnic markers - a sign, for instance, of the "costless community" that Waters (1990:118-21) finds in her study of third- and fourth-generation whites exercising "ethnic options" in the United States. But Lee's argument is stronger here: for Korean migrants, eating authentic kimchi is a form of resistance to attempts in Japanese society to erase their culture. In this case, bodily habits, tastes, or practices sustain a subordinate collective memory, and the body is a particularly important resource for those who lack other means.

The body is also an important site of subordinated memories in Gibbons's reflections on popular memory in Ireland around the time of the centennial of the 1798 rebellion. Taking Ulysses and other of James Joyce's writings as his texts, Gibbons (2001:145) shows "the reverberations of the past" entering the body "at a somatic level." He sets the figure of the flâneur encountering the heterogeneous temporal elements coexisting in Dublin against the figure of the monument, which fixes official history. Walking in the city, he argues, Joyce's characters move through time as well as space, but in dislocated, preconscious ways that may differ from their conscious intentions and attitudes. Somatic memory is involuntary memory triggered by movement in space, the chance observation of a building here or a building there. For one character in Ulysses, Kernan, "the wayward sentiments precipitated by the physical act of walking are at odds with his official deference towards colonial rule, as if his body doesn't know what his mind is doing" (p. 153). Nevertheless, Gibbons argues, the "jarring perceptual strategies of the colonial flaneur were all too aware of the nightmare of history and could not but register the reawakening of the nation as it attempted to throw off the dead weight of imperial torpor" (p. 150). This is a sort of Foucauldian "subjugated knowledge," existing alongside but perhaps also energizing the more formal cultural organizations and movements of the period that culminated in the Easter Rising of 1916 . Whereas Lee points to bodily practices that consciously sustain subordinate collective memory, Gibbons suggests that they can generate a subconscious sense of history that conflicts with official versions.

Similarly, Stoller $(1994: 642,641)$ examines contemporary spirit possession ceremonies of the Songhay people of Niger and Mali and argues that "spirit possession is an incontestably embodied phenomenon that triggers a myriad of cultural memories"countermemories "stored in movement, in posture, in gesture, in sound, odor and taste—in the flesh." Each spirit family represents a period in Songhay history (which is also recorded - though less powerfully according to Stoller-in text and oral epics). For instance, the Hauka spirits "mimic colonial personages" (p. 664) and date from 1925. In his analysis, Stoller challenges anthropological accounts of spirit possession in terms of functionalism, psychoanalysis, textual interpretation, and so on, and builds on Bourdieu's notion of embodied taste, among other sources, to critique the heavy bias toward text and discourse in the social sciences. He also wants to go beyond the sort of limited recognition of embodiment in which the body is just another sort of text, views that "strip the body of its smells, tastes, texture, and pain" (p. 637). Stoller also argues that embodied memory, by contrast to textual memory, is the site of critical, subordinate collective memory: "Spirit possession ceremonies spark Songhay counter-memories, which are ... stored ... in the flesh" (p. 65). 
The elderly Korean in Japan, the Dublin flâneur, the Songhay possessed by the spirit of a colonial governor: these can stand here for a strong embodiment thesis, the argument that social memory is carried in the body and that this sort of memory is consequential even alongside textual and monumental representation. The Korean example touches on themes of both identity and contestation; the Dublin example suggests that bodily memory may constitute a sort of prepolitical (in Hobsbawm's terms) memory that exists alongside and may animate more typically textual and organizational dimensions of memory politics; and the Songhay example raises issues of malleability and persistence, seeming to suggest that bodily memory may cross generations, transcending the limits of the body itself.

This strong embodiment thesis-viewing memory from the point of view of a "phenomenally-experienced individual body-self" (Scheper-Hughes and Lock 1987:6) — should be distinguished from two weaker versions more congenial to existing social memory studies. As Scheper-Hughes and Lock discuss, the body is also important as a symbol and as an object of social control. The former approach simply reminds us of the many ways bodies can be just another sort of text, how clothing, food tastes, postures, and so forth can represent. The latter approach examines how bodies and bodily experience are themselves influenced by macro-social processes of reproduction and regulation and micro-social processes of restraint and representation (Turner 1984:85-114). For instance, Igarashi's study of Japan's remembrance of World War II emphasizes the importance of the discursively constructed body as a symbol of national identity, tracing representations of the body through various postwar genres. Moreover, this "discursively constructed body" derived plausibility from the wartime regime's attempts to "create obedient, nationalist bodies by forging ties between nationalist ideology and bodily functions" (Igarashi 2000:13). In this account, the body as representation and the body as object of social control are linked. However, neither of these conceptualizations relies on the phenomenological experience of the body-self that grounds versions of the strong embodiment thesis. ${ }^{4}$ We focus on the latter thesis here because it presents the most puzzling challenge to sociologists and historians working on collective memory.

Stoller (1997:xvi) has made this challenge strongest and most explicit, using his studies of the Songhay to argue that "memory (and history) is an embodied phenomenon." He emphasizes that "embodiment is not primarily textual, that the human body is not principally a text; rather, it is consumed by a world filled with smells, textures, sights, sounds, and tastes, all of which spark cultural memories" (p. 85), and criticizes other scholarship on the body for persisting in ignoring the sensuous. But his argument remains ambiguous in its intended range: while Stoller sometimes seems to extend his critique to all collective memory, he implicitly limits it, elsewhere, to the memory of repression, to history from below, and to forms of perception in non-Western societies. This ambiguity raises important questions about the theoretical generality of the strong embodiment thesis because of the well-recognized historical shifts in forms and technologies of collective memory mentioned above. 
A broader application of the strong embodiment thesis has been argued most forcefully and influentially by Paul Connerton, in How Societies Remember, a theorization that explicitly authorizes the studies above, as well as many others. For Connerton, as for Flyvbjerg (2001), the social sciences are too obsessed with "viewing particular instances of behavior as the application of social rules" (Connerton 1989:29). This flaw, he argues, is characteristic of scholars as diverse as Winch (on moral action as rule governed) and Sahlins (on clothing as a system structured like a language).

Thus Connerton wants to challenge an overemphasis on what he calls inscribed memory throughout the social sciences. Habit memory, he says, has been neglected, although forgetting a habit is different from forgetting an event or forgetting a cognition. A ritual, for instance, is not just a symbolic representation of something else, not simply a text that needs decoding, but a matter of bodily repetition that is both performative and mnemonic. The importance of the body extends further. "Incorporated practices" in ceremonies, proprieties (such as bodily etiquette), and techniques (such as gestures) involve more than cognitive memory, and, Connerton argues, they are mnemonics for a sort of knowledge that does not exist independent of performance. In contrast to most of those who, like Stoller, have used his ideas since, Connerton (1989:102) suggests that this sort of memory may in fact be more conservative than discursive memory, which is more easily questioned, and his illustrations are often drawn from dominant cultures: for instance, "those practices through which the French nobility of the seventeenth century displayed their privileged status" are used to illustrate the force of "ceremonies of the body" (p. 84).

The strong embodiment thesis, then, points to a form of memory beyond discourse and symbols, arguing that this memory should be brought to the center of scholarly attention. How does the memory of Bloody Sunday look when we use this lens?

\section{BLOODY SUNDAY AND THE STRONG EMBODIMENT THESIS}

In the 1992 documentary, The Bloody Sunday Murders, a young woman faces the camera and begins to tell the story: "I want to tell you the truth about Bloody Sunday. ... I was two years old at the time but like everyone else in the community I lived with the memory of it. . . the memory is still as raw today as it ever was" (Gibbons 1998:102). And indeed, the popular memory of Bloody Sunday in Derry and more generally in Northern Ireland is widespread and powerful and has been highly elaborated in various forms over thirty years. There are some good reasons to think that embodied memory could be important in accounting for this power.

First, the "official" denial or silence about the traumatic meaning of the events in subordinate memory makes this case similar to other case studies on embodied collective memory, like that of the Koreans in Japan mentioned earlier (Lee 2000; see also Kleinman and Kleinman 1994; Skultans 1999). Second, embodied memory should also be particularly significant in the Bloody Sunday case because a number of studies have shown that, more generally, Catholic and Protestant group identities in Northern Ireland are systematically encoded in embodied practices in ways that 
sustain those identities. For instance, Kelleher (2003:56) found that his informants in a town in the west of Northern Ireland "mapped their social world through their moving bodies. Those moves were acts of memorization, forms of practical consciousness, and they elicited narration." The colonial past was articulated partly "in the practical consciousness that guided their bodies through space" (p. 59). Beyond these informal incorporated practices, too, there is also a strong tradition of more formal ceremonial parades in Northern Ireland, parades that create and sustain difference, and articulate critique and legitimation (Bryan 2000; Conway 2005:114-16; Jarman 1997).

So, because of official silence, and also because of this well-recognized encoding of Catholic and Protestant identities in embodied practices in Northern Ireland, this is a case where we might expect embodied memory to play a significant role. And indeed there is some evidence that for those who experienced the 1972 events memory is, in part, visceral. As one relative of a victim says, "I live and breathe Bloody Sunday. . . . you feel like you're carrying this baggage around with you" (Gartner 1998:126). Some march participants' extended reflections include poignant evidence that the bodily repetition of the commemorative marches is an important site of memory, among others. For one participant, and much like Gibbons's Dublin flâneur, "memories come flooding back" when he retraced his footsteps on the march's twenty-fifth anniversary, and he elaborates in detail his experience of that day in 1972, continuing:

So he ran, we ran, we continued on over Glenfada Park over to Lisfannon Park and we stood there, we heard the roaring and the shouting and all of a sudden we heard the shots.... and this went on for what seemed like an eternity.... me and Harry went down and we found one of the men was lying, his name was Barney McGuigan, he had been shot in the head, he had gone out with a white handkerchief to help a person who had been hurt.... and of course the paratroop regiment had come in at William Street over by the lovely church there the Presbyterian church and they were all around the Bogside.... So it was an absolutely terrible time. It felt as if, you know. . . . it was January. . . . it was quite a cold day and a little bit wet but it felt after we heard the news all those people had been killed and injured as if the clouds had come down, the dark clouds, and they were just hanging above your head, the whole city was quiet. ${ }^{5}$

For another informant, too, "all those memories come flooding back" on the annual commemorative march:

It is a very emotional thing for me. I don't think I can convey adequately. ... The last march, for example, and I normally walk alone. I don't walk with other people. I walk alone and I like to reflect. And I remember as I . . I remember the day so well. It is a carnival now. .. . That wasn't like what it was like on the day. ... It is a most nauseating thing. And I don't think I will ever forget the feeling in my stomach when I realized for the first time that they were using lead. I hadn't seen lead used before. I was involved in all sorts of protests and things . . . so I couldn't believe they were using lead. Twenty thousand people ... men, women and children. And here they were using lead and it was skipping off the ground. And then, the reality, this awful coldness that comes over you, that here we are, 
they're dead, there on the street, they're dead, their skulls are burst open and grey matter is coming out. And they are lying there.

And another observes:

I don't think I have ever personally, emotionally recovered ... from the events of Bloody Sunday. ... and I think most of the people who were there at that time have not recovered from it.... and the first few times I went to the march and even yet ... we gather in Creggan when the march starts off. ... And we go down the hill from Creggan. ... sometimes I can feel the hair on the back of me neck because it brings back so many memories you know. . . . and I always remember the first, the original march on the first day.

For these participants, then, at least one dimension of the memory of Bloody Sunday seems to be experientially located in the "phenomenally-experienced individual body-self" as evoked in the embodied repetition of the annual commemorative march. Theorists of embodiment as a site of collective memory seem right to draw attention to this neglected experiential power. But the existence of these experiences does not guarantee their generality or significance for collective memories.

Raw experiences like the ones above are not commonly reported. While this may be partly because of implicit norms defining them as irrelevant to discussion of Bloody Sunday, it seems more likely, in this case, that the experience of another longtime marcher is at least as common, if not more so:

The Bloody Sunday march doesn't for me any more because it is over the same route.... it goes on far too long the route of the bloody march for mid-winter ... so I don't. ... I mean I feel a lot of emotion for Bloody Sunday when I'm listening to the evidence at the Saville Tribunal or simply when I think about it ... but on the march no, no I don't actually ... it's a ... let me say it is a political campaigning that I'm in.

For this respondent, the most common meaning of the commemorative march was its political meaning. Understandings of participation in the commemorative march as "a means to an end" and "a show of support" were much more common than understandings centered on what Connerton would call habit memory: "It is the biggest sort of public statement if you will of people. . . . It reflects the feeling of the time." Even where physical reenactment and copresence carry significant personal meaning, their importance is understood in terms of signification, the body as another sort of sign, rather than as phenomenologically evocative for memory production:

People can show their support though the march.... The march was vital, it still is vital to put across the support for the families in relation to what they were trying to achieve.... People identify themselves with the families as well and be on the march, and see the families and listen to the platform and be able to say to their own families I was there. That's important. Because it was important to educate the world in relation to what happened on Bloody Sunday too as well. If you look at it on a yearly basis, in the last ten, twelve years, it has actually been carried on TV. 
Even though a few informants speak powerfully of embodied memory, then, many more understand their experience as a signifying practice, supporting only a weaker understanding of embodied habit as a form of collective memory. This suggests that we need to reexamine the place of discursive practices in theories of embodied collective memory.

\section{BEYOND THE STRONG EMBODIMENT THESIS}

A good deal of the impact of the embodied memory arguments of Stoller, Connerton, and others derives from their negative argument about the supposedly undue focus of the social sciences on inscription, on decoding, on rule, and on language. However, as the discussion above begins to suggest, and even setting aside collective memories that take purely discursive forms, like books and museums, those memories embodied in habitual, repetitive practices are often experienced mostly as signifiers. We are left wondering, then, about the relationship between bodily and inscribed memory, about whether the inscribed memories most collective memory studies are concerned with are in fact of little consequence, as the critique of an overemphasis on inscription implies.

We are left wondering about the relation between inscribed and embodied memory because the structure of Connerton's (1989:4-5) argument involves "a progressive narrowing of focus":

If there is such a thing as social memory ... we are likely to find it in commemorative ceremonies; but commemorative ceremonies prove to be commemorative only in so far as they are performative; performativity cannot be thought without a concept of habit; and habit cannot be thought without a notion of bodily automatisms. (See also p. 71)

But this overall argument, stated so absolutely, invites doubt for four reasons.

Most relevant to our issues here, "social memory" may exist beyond commemorative ceremony - in historical reconstruction, symbolism, and oral history, for instance, as well as in texts, images, monuments, museums, and so on. Connerton draws a sharp and somewhat idealized procedural distinction between formal history and social memory. While recognizing instances in which they mutually influence each other, he wants to preserve the realm of social memory for "more procedurally informal and more culturally diffused" narratives of the past (Connerton 1989:16). Yet whether our awareness and understanding of aspects of the past derive originally from the formal work of historians seems immaterial to their significance, especially in complex literate societies, since there is a strong empirical relation between more procedurally formal and more informal memory construction processes. So, for instance, the work of professional historians can evoke-and change-more informal social memories (Spillman 1997), and, conversely, informal understandings of the past can influence the work of professional historians (Schwartz 2005). The interrelations between formal, "inscribed" histories, commemorative ceremony, and informal social memories are more complex than Connerton allows. 
Indeed, many contemporary commemorative ceremonies have an impact on informal social memory through inscription, as much as performance, especially if they are conducted in ways that extend the experience in space and time-as the significance of the TV broadcasts to the participant above suggests.

Oral histories also seem to challenge Connerton's limitation of "social memory" to commemorative ceremony: indeed, before moving to his central arguments about bodily habit and memory, he treats oral histories as the prototype of "social" as opposed to "formal historical" memory (1989:17-21). He does not pursue the significance of oral histories, but they do not seem to fit his claims that social memory is essentially ceremonial. In village life, as opposed to urban contexts, he points out, daily recounting and gossip mean that "the village informally constructs a continuous communal history of itself: a history in which everybody portrays, in which everybody is portrayed, and in which the act of portrayal never stops" (p. 17). And even where oral history is constructed in collective performances, as in the "ceili" Glassie (1982:chap. 3) describes in a late-twentieth-century Ulster village, these performances are too contingent and informal to be usefully labeled "ceremonial."

So, contrary to Connerton's account, social memory extends significantly beyond commemorative ceremony. Nevertheless, Connerton is right to emphasize the performative core of such ceremony and thus stress the importance of performativity where collective memory is embedded in commemorative ritual. However, he understands performativity as an intrinsic, invariant connection between the ceremonial performance and the social memory performed: "It is intrinsic to the nature of ritualsbut not of myths - that they specify the relationship that obtains between the performance of the ritual and what it is that the participants are performing"; therefore, "the structure of rituals has significantly less potential for variance" (Connerton 1989:57). Performativity in ritual is thus understood as "encoded" in actors' invariant utterances, postures, gestures, and movements; habit and the body are the true carriers of collective memory.

Yet this understanding of ritual ignores important elements of performance, oversimplifying conditions for its success-and thus for the successful persistence of collective memories embedded in ceremony. As Alexander (2004) argues, the conditions of ritual performance include not only the actor (and her utterances, postures, gestures, and movements) but shared systems of collective representations, observers/audiences, means of symbolic production, mis-en-scène, and social power. Whether these conditions are successfully fused is contingent and becomes much more contingent in complex, differentiated societies. This more nuanced theory suggests that the importance of the actor's "body-self" as an experiential and representational carrier of collective memory is significantly overestimated in Connerton's identification of commemorative performativity with bodily habit. Bodily memory is certainly not sufficient to account for social memory (even if we restrict social memory to commemorative ceremony), because the ceremonial "encoding" of the past also relies on, and may be evident in, other performative conditions besides the embodied actor. 
If embodied, habitual memory cannot provide a sufficient account of social memory, is it at least necessary to any such account? Connerton suggests that ritual physical enactment intensifies and clarifies meaning in ways that are not possible when memory is inscribed, and thus it remains an essential grounding even in complex, literate societies. For him, ritualized physical enactment is inculcating and unambiguous in a way no text could be: "The limited resources of ritual posture, gesture, and movement strip communication clean of many hermeneutic puzzles" (Connerton 1989:59). The implication is that authentic collective memory is necessarily embodied, and inscribed memories are essentially weaker, more challengeable, and more changeable:

Both commemorative ceremonies and bodily practices ... contain a measure of insurance against the process of cumulative questioning entailed in all discursive practice. This is the source of their importance and persistence as mnemonic systems. Every group, then, will entrust to bodily automatisms the values and categories which they are most anxious to conserve. They will know how well the past can be kept in mind by a habitual memory sedimented in the body. (P. 102)

While recognizing the epochal shifts in memory's means and mode of production that occurred with literacy and increasing social complexity, Connerton suggests that bodily, habitual memory remains essential to preserving collective memory.

Yet this claim relies on arguments that embodied memories involve a sort of prediscursive transparency and transgenerational immutability that seem hard to sustain. An actor's postures, gestures, and movements are as much potential sources of "hermeneutic puzzles" and ambiguity—both to themselves as performers and to their audiences - as are the textual elements they draw on, and thus just as vulnerable to performative failure and "cumulative questioning." Geertz (1973:6-7) memorably introduces his "interpretive theory of culture" with a riff on Ryle's example of boys rapidly contracting their eyelids-embodied significance that rapidly decomposes into multiple possibilities of "twitches, winks, fake-winks, parodies, [and] rehearsals of parodies." ${ }^{\prime 6}$ Even embodied experience will not guarantee the performative success of the idealized commemorative ritual — and the openness of embodied habit to variant interpretation would be multiplied in its generational transmission. Conversely, embodied memory may be a relatively unimportant element in successful commemoration, which, as noted above, depends on the fusion of a range of performative conditions rather than any single element. Indeed, it is possible to imagine successful commemoration that reduces the significance of the actor's embodied experience to his or her presence before a camera, structured interaction with exhibits at a museum, or capacity to download a memorial Web site simultaneously with other group members.

\section{DISCOURSE, ORGANIZATION, AND EMBODIMENT IN THE MEMORY OF BLOODY SUNDAY}

So despite implications to the contrary, Connerton's argument does not in itself undermine approaches to collective memory that focus on and assume the importance of 
"inscribed" memories. By drawing an unsustainable distinction between formal, inscribed history and memorial performance, overemphasizing commemorative ceremony at the expense of oral history, invoking a notion of performativity that is too thin and essentialist, and underestimating the potential ambiguity in embodied, habitual performance, Connerton oversimplifies and exaggerates the distinction he is drawing between inscribed and embodied memory. We can illustrate these issues by attending to some of the many ways the few reports of embodied memory of Bloody Sunday noted above are embedded in and made possible by their discursive and organizational context.

It is important to emphasize, first, that although Bloody Sunday was officially ignored for over thirty years, and although the commemorative march has been a centerpiece of contesting popular memory, this memory has also been richly elaborated in many inscribed forms, as noted above. Some of these sites of memory are indistinguishable from the sorts of formal history that Connerton claims are less authentic and less powerful than embodied social memory. In this context, it becomes impossible to make any sharp empirical distinction between, or to assign relative importance to, embodied performance and inscribed history. And experientially, inscribed history inheres in embodied performance.

Thus, for one marcher mentioned above, for whom walking in the annual event generates "a flood of memories," part of the experience is centered on the concentration of symbols:

I go on the march and I get into company with people and we just do the route and of course we watch the sort of 'em. ... they made up certain hoardings you know. ... Photographs, large photographs of the thirteen people who were murdered on that particular day.... so they would all be around the Creggan estate ... you would watch them. And there would be a lot of graffiti around, a lot of flags and things like that.

For another participant, "the march is only part of the commemoration.... but it is in one sense the most meaningful . . . because it is the biggest and because it is a public statement and ... specifically the march where they lay the crosses on the monument. ... I find that quite moving." Indeed, for yet another, monuments are not simply "official history" (in the contrast drawn by Gibbons) but an obviously popular site of memory: "The notion that there should be a monument to the dead of Bloody Sunday was an obvious one.... in a country of monuments ... we're not the only country like that in a period of struggles." Yet another links his evaluation of the most successful march to the publication of a book:

I think probably the major march was the 25 th, the 20 th or the 25 th anniversary, it may have been the 20th, it was the year that Don Mullan's book ... it was the year his book came out ... and that was very significant.... I talked with a very good friend of mine ... who is a lecturer. ... and he told me the only way you can be sure that this is going to be preserved is get a book published.... when the historian comes to do his research he will consult the library and get his information. 
Symbols are important to the experiential memory here: the sharp distinction that Connerton and others draw between embodied and inscribed memory cannot be sustained, and "formal" history is bound in multistranded reciprocal relations with "social memory."

Second, Connerton's ultimate focus on ceremony, excluding oral history, is also difficult to sustain. For one march participant with "you know flashbacks of particular circumstances involved," such flashbacks were triggered by conversation generated by the organization of Bloody Sunday events, by "people talking to one another ... by people attending the Bloody Sunday events in and around the week of Bloody Sunday." For this man, as for others, the mobilizations surrounding Bloody Sunday events-including books, films, and museums, as well as the march-brought private memories to the surface of collective conversation. A process in which Bloody Sunday commemorative organization triggers collective conversation is also evident in memory transmission:

\begin{abstract}
A lot of young people ... want to know what happened on Bloody Sunday. Ok it is a new generation but the same stories are carried down the line-you know what happened on Bloody Sunday Dad, were you there on Bloody Sunday, and so on.... But we must remember also that Bloody Sunday is in their face, in relation to the [Saville] Inquiry, because it is in the newspapers every week, is on the TV every night, and so they are being educated about Bloody Sunday. And through their mentors or elder generation they are being told about Bloody Sunday.
\end{abstract}

Third, even if we focus only on ceremonial performance, as Connerton ultimately does, the ceremonial encoding of the Bloody Sunday memory is conditioned by important organizational and discursive factors that seem to reduce significantly the importance of the actors' body-self for the memory in that performance. Even the first commemorative reenactments took place against an explicit background history of intensive organization and of various and sometimes competing discursive frames.

One central figure recounts at great length the history of civil rights activism and conflict in Derry in the years leading up to Bloody Sunday, noting a variety of activist groups and traditions and elaborating on the strong activist organization of the period:

So Derry Citizens Action took on the entire civil rights function. It was well organized, well disciplined. ... we had an army of stewards which we trained of about 1,500. These 1,500 stewards were trained by the Derry Citizen Action Committee. After meetings held five nights a week in little halls all over the place where the philosophy of Gandhi and Martin Luther King was expounded. ... and we were training, inculcating people into how we organized marches and how we stop people from engaging in violence.

As another informant noted, "The Bloody Sunday issue wasn't, wasn't a standalone issue in those years in the way that it subsequently became."

In the 1980s the organization of the march came to be dominated by Sinn Féin, which "mobilizes every year and brings quite a lot of people. ... stewards for the 
march are not formally organized by Sinn Féin it just tends naturally to be Sinn Féiners who come forward to offer themselves as stewards." As noted below, Sinn Féin's organization of the march was contested, but even one critic points out that "in fairness to Sinn Féin if they hadn't taken on that role and organized the march . . . it probably would never have developed into the massive demonstration it did develop into."

Beyond these organizational conditions, the meaning of the march was also always already inscribed in preexisting discursive frames. Bloody Sunday "immediately fitted into the pattern of" other events_-"Bloody Friday and some other massacres. ... there was another Bloody Sunday in 1920," so "the distinctive reaction, if you like, of both communities in Northern Ireland was to react in traditional ways."

Discourse and inscription were important even before the first commemorative march. The British government's official Widgery report had exonerated the soldiers involved in 1972, but even by 1973, several legal critiques had been written. One critique was written for the Northern Ireland Civil Rights Association (NICRA), which was an important march organizer in the first decade. Other forms of "inscription" were already evident early, including several critical songs and poems, extensive press discussion, and planning of a memorial (Conway 2005). In the month leading up to the 1973 commemoration, the march was extensively advertised, with printed lists of the names of the dead. The memory of Bloody Sunday was always already inscribed.

And contrary to Connerton's claims, the meaning of that memory was never unambiguous, but understood in very different ways, in a discursive field structured by dichotomies between peace and violence, constitutional and armed struggle, personal memory and public claim. From the beginning, memory "entrepreneurs" competed over the interpretation of the commemoration. In the early years, a number of social movement organizations laid claim to the memory of the Bloody Sunday dead. NICRA and Sinn Féin were the most significant. Between about 1973 and 1978 NICRA and Sinn Féin held different and sometimes directly competing commemorations. The NICRA commemorations were smaller and more directly attuned to victims' families while promoting democracy and nonviolence. The Sinn Féin commemorations appealed to the memory of the Bloody Sunday dead to validate Republican goals and unite Republicans (Conway 2005).

In 1973, in fact, two rival marches were held on the same day. NICRA organized a march supported by families of victims-intended to be nonpartisan, silent, without banners and flags, and ending with a wreath laying. NICRA pamphlets, promotions, and organizational records all stressed similar themes: "Remembering that the original march was held as a peaceful demonstration, we must ensure that, in accordance with that ideal, this commemoration shows an example of dignity and respect to the world or else we reject the principles of those who died and we discredit their memory" (Derry Journal 1973:1). About two thousand attended. By contrast, the significantly larger Sinn Féin march, attended by about seven thousand people, included marching bands, banners, flags, and speeches, encouraged marchers to support the Irish Republican Army (IRA) and the armed struggle, and challenged policies of internment and special courts. A year later, public notices in the Derry Journal in January in memory 
of the dead expressed these contrasting meanings. For Sinn Féin, the march was in memory of the dead "butchered by the 1st Batt. Britain's Parachute Regiment." But for the civil rights association, a commemorative march was held because "13 Died for Their Rights and Yours Two Years Ago in Derry" (Derry Journal 1974).

After about 1978, Sinn Féin was the main organizer of commemoration until the early nineties. But competing meanings played later, too, in ongoing commentary and challenge to Sinn Féin's dominance. Public criticism of its more radical, politicized interpretation of the memory continued unabated. Some of those who had been present at the original events withdrew from participation: as one family member said in 1978, "No way will I allow anyone to use Barney's name to justify more killing. . . . no one's ever asked the families if their names could be used in support of more violence" (Sunday World 1978). Summarizing the competing positions, one article suggested that "some will accuse the march organizers of misusing the memory of the dead, while others maintain that such a show of defiance is the only adequate memorial" (Sunday World 1978).

These competing meanings structure and dominate participants' understandings of the meaning in the commemorative march over the years, making collective memory embodied in the commemorative march much more ambiguous than Connerton's argument would suggest. On one understanding, for instance, the number of people attending the march was an indicator of support for republicanism and the IRA: as one participant wrote, "I had a feeling of low morale which has always accompanied such marches, about the size of the turn-out. Would it be a smaller march than last year? Would a low turnout mean something sinister, and would the press read into it the defeat of the I.R.A.?!!!” (Boyle 1978). For an opponent of Sinn Féin, on the other hand,

Sinn Féin strategy has been to hijack everything in sight, including history. The march we have now ... there are bands. ... I don't agree with that at all. ... one of the things which I ask myself is ... are these people true republicans? Well you see I don't believe they are. I think they are Nationalists. And part of that is that we mirror some of the Loyalist type demonstrations. So you have bands.... There is too much of a carnival thing with a band. I think that should be a civil rights march. ... if there had to be any type of music we should be singing the civil rights anthem-We Shall Overcome-we sang that that day.

For another,

It was a Sinn Féin organized march. I always went to it ... and lots of other people did. ... I made the argument at the time that ... if we didn't march we were simply leaving the issue to Sinn Féin ... and that wasn't right either... . I think the extent to which Sinn Féin does dominate the march is a bad thing ... not because it is Sinn Féin but because it is difficult to explain that the Bloody Sunday itself is not simply a Nationalist issue. . . when these forces of the State come into an area and kill its citizens that is everybody's concern.

In contrast to Connerton's claims, too, but as many other studies of collective memory would suggest, the history of the march shows a marked presentism, with changing themes and claims according to changing contemporary concerns (Olick 
and Robbins 1998; Spillman 2003). Not only is the demeanor and affect of the original march irrecoverable, and the surrounding physical environment and route of the march changed, but, more important for Connerton's claims about the persistence of embodied collective memory, banners and slogans reflect political grievances and demands of the day. At various times, the march emphasized different contemporary issues, like hunger strikes, the right of Republican prisoners for political status, or show trials. For one march organizer, indeed,

\begin{abstract}
some of my better memories of the march have been when we pinpointed other human rights issues. Which we often did. ... one year we did the Birmingham Six. And that's ... I suppose I wouldn't use the word enjoyment but I got more out of that march that year I think than any other time. The whole buildup, the political issue, the Birmingham Six is a really hot issue at the time as well... There is a great sense that we were really doing something ... that this march wasn't about remembering what happened on Bloody Sunday in campaigning for it . . . but it was also about how others have been wrongly affected by the conflict.
\end{abstract}

From the early 1990s, too, with the Northern Ireland peace process and the Bloody Sunday Justice Campaign to reopen the British inquiry, a new emphasis on negotiation developed. Also in the 1990s, the march increasingly situated the 1972 events and their aftermath as part of a broader, global story of oppression and challenges to domination (Conway 2003, 2005). ${ }^{8}$

\title{
DISCUSSION
}

All this might suggest that the only way bodily memory can be consequential is if we understand the body as another sort of text, a genre of representation, a weak embodiment thesis at best. Against this, proponents of the strong embodiment thesis might be inclined to argue that, in focusing on the ways social life is primarily "inscribed," we continue to express the false consciousness and bodily dissociation of the intellectual, and understanding embodied memory-indeed, embodiment in general-remains fundamental to any future inquiries about collective memory. More productive than either of these alternatives, we would argue, would be to narrow and specify the strong embodiment thesis, opening up for investigation the circumstances and ways in which bodily memory might occasionally influence textual memory, and vice versa.

It is helpful to begin to think through the conditions under which embodied memory is important by considering how embodiment might be relevant to the three issues Olick and Robbins (1998) identify as central in social memory studiesidentity, contestation, and transmission.

First, the arguments about bodily memory clearly sensitize us to one way group identities are sometimes constituted-processes we have tended more often to think of in terms of disembodied narrative and other discursive and symbolic forms. The key question here, though, is this. Under what conditions will bodily memorysuch as the Korean migrant's experience of kimchi, the Dublin flâneur's involuntary somatic memory of repressed history, or our respondents' occasional reports of the 
way visceral memories "come flooding back" during the march-make the transition C. Wright Mills (1959:8) characterized as that between "personal troubles" and "public issues"? Even a large aggregate of individuals with the same incorporated memories would not seem to be important to collective memory, unless those memories were mutually symbolized, inscribed in suitable genre, and, perhaps, mobilized in memory politics (Smelser 2004:48). ${ }^{9}$

If these broader conditions for the performance of group memory are present, though, the interactional sharing of embodied memory may indeed heighten and sustain some forms of identity by comparison to others where memory is more purely discursive. In one of the most persuasive phenomenologically influenced theories of embodiment, Frank identifies communicative potential for recognition as one type of body use in action. In some circumstances, embodied experience may significantly enhance narrative communication: "What communicative bodies are about is the capacity for recognition which is enhanced through the sharing of narratives which are fully embodied. ... It is when narratives are spoken from the experience of the body that they can be shared most readily" (Frank 1991:89). So, for instance, although Bloody Sunday was one among many related events of the time, we could hypothesize that this particular event later became one of the central memories of the Troubles precisely because of the heightening performative power of the embodied memory in the commemorative march. Focused comparison of similar groups or events varying only in whether or not embodied memories are central and public would, then, be one way to narrow and specify the strong embodiment thesis.

Second, similar strategies of conceptualization and research design would help specify the significance of the strong embodiment thesis for contestation and collective memory. Beyond the question of whether and when embodied memory could heighten and sustain collective identities in general lies the question of whether and how embodied memory might function in memory contestation. Studies like those of Lee on the elderly Koreans and Stoller on Songhay spirit possession argue that embodied memory is itself a relatively neglected form of collectively understood contestation, preserving a sense of the past that conflicts with dominant constructions. However, as we have argued above, the mindful body's memory, critical or not, does require some form of collective inscription and mobilization to become more than "personal troubles," even if such inscription exists only in the form of oral history for the very powerless. But if views that embodied memory can be a form of contestation seem too solipsistic, the question of whether it is an underestimated resource for explicit, inscribed, organized contestation is worth exploring. Are rhetorical forms and performative genres that-to some extent-appeal to or build on embodied memory, like the Bloody Sunday march, likely to be more effective tools in the politics of memory? Again, focused comparisons could help answer this question. It would be important, however, to distinguish between the use of bodies as symbols of political support-the point of march attendance for many of our respondents quoted above-and the potentially 
improved capacity for mobilization and claims making that might be generated because of the experiential and communicative power of "narratives ... spoken from the experience of the body." 10

The third theme of sociological work on collective memory is the issue of its malleability or persistence in intergenerational transmission (Olick and Robbins 1998:128-30). Connerton's argument suggests that bodily memory is a neglected source of persistence in collective memories. On this account, incorporated memory is less constrained by cultural genre and instrumental cultural production than inscribed memory: because it is implicit, it may be more difficult to censor, discipline, or challenge, and thus more resilient. On the other hand, and contrary to Connerton's argument, performativity may involve inbuilt change; incorporated memory in such rituals as commemorative marches will vary because they are never done exactly the same way twice. Indeed, on Alexander's more elaborated theory of social performance, the memories reproduced and emergent in such performance will be highly contingent. How much and how incorporated memory encourages malleability or persistence remains an open question that sociologists and historians of collective memory will need to address in more empirical and theoretical depth than anthropologically grounded studies and phenomenologically grounded theories have yet accomplished. As discussed above, however, the ways that organizational and discursive conditions generate both embodied, experiential memory of Bloody Sunday and variant interpretations of its meaning suggest that embodied memory will be more malleable than persistent.

The persistence of embodied collective memories across generations seems especially problematic. Whereas the Korean migrants' grandchildren no longer find kimchi so significant to their identity (as one would also expect, given Schuman and Scott's [1989] findings about generational differences in American memory), the Songhay apparently transmit historical experience going back centuries in the embodiment of spirit possession. There seem to be two sorts of mechanisms by which such transmission might be achieved. One might be more strictly "bodily"- the sort of preconscious inculcation of identity markers as occurs, for instance, with gender (see, e.g., Young 2002). Given the tectonic shifts in forms of memory noted above, however, it is hard to imagine that this sort of transmission would remain in our time purely doxic (Bourdieu 1977): even preconscious bodily memories seem likely to be culturally thematized as orthodoxy or heterodoxy by someone somewhere. Lee does not tell us about Korean entrepreneurs or social clubs in Japan importing and promoting authentic kimchi, but it seems likely they exist. And as we have seen, too, embodied memory of Bloody Sunday is heavily laden with prior organizational and cultural work. So intergenerational transmission of collective memory through purely preconscious inculcation of bodily habits seems unlikely. ${ }^{11}$

The second sort of mechanism by which transmission of bodily memories would occur would require their integration in-inscription in-genres that allow their inculcation and repetition across generations. Stoller's spirit possession would seem a case in point. Unlike most existing research on embodied memory, Stoller's case does indeed involve memory transmission across generations. But here, and contrary 
to his argument, it seems that it is inscription in a distinctive and flexible performative genre that is the fundamental condition for transmitting repeated bodily experiences. So mechanisms by which embodied memories might be transmitted seem linked to processes of inscription: understanding intergenerational transmission of embodied collective memory seems to require a deeper understanding of the ways inscribed memory might generate embodied memories and a return to the sort of cultural analysis that Stoller and Connerton reject. ${ }^{12}$

In the Bloody Sunday case, as we saw briefly above, the memory lives with many young people, and children carrying crosses are a familiar part of the march. As one respondent said: "I would have been on the first march in a pram.... I was born after Bloody Sunday. ... It was actually part of family life. We would always have attended it... I I come from a republican family." Yet there is little indication that the embodied performance of the march plays any more significant a role in this transmission than the collective conversation generated by the organizational work of memory entrepreneurs, than the TV stories of the new inquiry, than the new museum, or, especially, the related films. A number of respondents spoke critically, and at length, of the two Bloody Sunday movies and their "role in shaping the narrative in people's minds." The embodied experience of the march again seems to be only one small part of the organized and inscribed collective memory. Moreover, several key participants wonder whether the annual commemorative march will continue beyond the expected report of the Saville Inquiry, through new political contexts: "The march was a means to an end. If we get that end then we don't need the means any more. ... Other people have a different point of view. I know some people would like to see the march go on every year."

Theoretically, then, the question of the persistence, change, or loss of collective memories over generations and through changing historical contexts brings an emphasis on embodied experience into sharpest contradiction with a more traditional emphasis on discourse and organization. Again, the neglected question of the relations between inscribed and embodied memory seems crucial. For instance, could media highlighting of Bloody Sunday history encourage new generations to continue the tradition of commemorative march participation, generating eventually a form of preconscious, embodied memory from a broader organizational and discursive context? More broadly, under what conditions could embodied memory really be transmitted, extending its impact in time and space?

These sorts of questions are generated when we begin to wonder about the implications of "incorporated memory" for sociological and historical work in social memory studies, but such questions have not been addressed because existing work draws too sharp a dichotomy between processes of inscription and processes of embodiment. Our aim here has been to open the topic for reflection by exploring the case for the importance of embodiment, assessing its limitations, and suggesting how insights from embodiment theory may be examined in more focused ways in future studies of collective memory and identity, collective memory and contestation, and the persistence or malleability of collective memories. 
In our view, sociological theories of collective memory including insights from theories of embodiment will need to make two further moves. First, the level of analysis should be shifted from the individual's embodied experience to the interactional situation (broadly conceived), along the lines suggested by Collins (2004:chap. 2), in his recent theory of embodied processes of mutual focus and entrainment in interaction ritual chains (see also Goodwin 2000). This move would help avoid the somewhat solipsistic tendencies of an exclusive focus on the body itself. Second, though, such theories will require a further move, or a return, to examining cultural processes at a level of analysis beyond the individual and the interactional situation. The arguments against the significance of discourse evident in theories of embodiment seriously limit their explanatory power, because embodied experience is itself always shaped within preexisting discursive fields. As we have argued, for instance, embodied memory in the Bloody Sunday commemorative march is deeply conditioned by elaborate preexisting interpretation and definition of the situation. Cultural categories, symbols, and genre define situations within which embodied experience, including embodied memory, is meaningful.

\section{CONCLUSION}

The strong embodiment thesis, that incorporated experience is a crucial site of collective memory, has become increasingly important as a focus of collective memory scholarship. Connerton's widely cited argument for embodied memory—and against a focus on discursive forms - is theoretically subtle and empirically wide ranging, and many have clearly found it productive as a sensitizing theory. Because of its influence, and because sociologists have so far focused mostly on discursive and textual forms of collective memory, this challenge to the importance of the discursive and the textual deserves closer attention.

We have argued that, although this perspective does indeed illuminate aspects of social memory that have been neglected, incorporated memory plays a much less central role than Connerton and those who follow him wish to claim. Theoretically, the strong embodiment thesis is limited because (1) the sharp distinction Connerton wishes to draw between informal, performative social memory and formal, inscribed history cannot be sustained; (2) even leaving aside the issue of formal history, Connerton overemphasizes repeated ceremonial performance at the expense of more informal oral history or collective conversation; (3) he invokes an overly reductionist notion of performativity focused on bodily habit; and (4) he underestimates the ambiguity in embodied, habitual performance. Because it absolutizes the distinction between embodied memory and textual memory, Connerton's strong embodiment thesis offers no way to understand the complex reciprocal relations between inscription, organization, and symbolization, on the one hand, and embodied, habitual memory, on the other. When we consider the potential impact of inscribed memory on embodied memory, the latter seems to play a much less central role than Connerton's widely cited theory would suggest. 
The Bloody Sunday commemorative march, held for more than thirty years in Derry, illustrates these theoretical issues, even though there are several reasons to think that this might be a strong case for theorists of embodied memory. Although this case study is simply an illustration, our observations will likely sound familiar to any student of collective memory in contemporary societies. The origins, development, and change of the Bloody Sunday commemorative march are driven by discourse and debate.

First, and as one might expect, the immediate experience is rapidly inserted into preexisting discursive frameworks and repertoires of contention supported with long-standing organizational resources. There is no strong boundary between formal history and informal memory practices because the events of 1972 are always already inscribed in discursive frameworks with deep roots in formalized, textualized histories. Second, organized, preinscribed events generate not only embodied memory but collective conversation-an agenda-setting process that escapes Connerton's categories, even though he sometimes sees oral history as the sort of informal memory he wishes to counterpose against formal history. Third, the performativity of the Bloody Sunday commemorative march involves much more than the embodiment Connerton emphasizes. Connerton overestimates the significance of the actors' "body-self" as an experiential and representational carrier of collective memory in performance. Alexander's (2004) broader theory of ritual performance-and in particular the emphasis on shared symbolic codes and means of symbolic productionaccounts for much more of what we see in the history of the march, and the persistence of the Bloody Sunday memory. Fourth, the social memory expressed in embodied performance is not unambiguous and transparent but multidimensional, conflicted, and changing. The supposedly transparent habitual performance of the march allows for enormous ambiguity that Connerton cannot theorize. At any given time, the meanings of the march are multiple and contested: competing meanings, grounded in discursive oppositions between peace and violence, constitutional and armed struggle, remembrance and political claim, are mobilized by different memory entrepreneurs, march organizers, commentators, and participants. And the meanings of the embodied practices embedded in the Bloody Sunday march shift frequently over a few decades, according to contemporary concerns.

With these considerations in mind, we have suggested that insights from theories of embodied collective memory may be better developed in focused comparative studies that examine the ways bodily memory and textual memory may influence each other in constituting group identities, in the cultural politics of memory, and in change, persistence, and intergenerational transmission.

Acknowledgments: This article is based on research first presented at the Conference on Collective Memory and Symbolic Interaction at Northwestern University in June 2004, sponsored by Northwestern University's Weinberg College of Arts and Sciences, the Department of Sociology, and the Society for the Study of Symbolic 
Interaction. Thanks to Gary Fine and Aaron Beim for creating this stimulating event and to the participants for their helpful reactions. Audiences at the World Congress of the International Institute of Sociology in Stockholm in July 2005 and the Annual Meeting of the American Sociological Association in Philadelphia in August 2005 also helped shape our arguments. Thanks especially to Gary Fine, Andreas Glaeser, Russell Faeges, and anonymous reviewers for detailed comments, and to informants in Derry for their generosity in sharing their experiences and observations.

\section{NOTES}

1. For a sense of the theoretical advances in this area, see the discussions in Budgeon 2003, Freund 2001, Halton 1992, Howson 2004, Newton 2003, Skultans 1999, Williams 2003, and Witz and Marshall 2003. See also the wide range of issues opened up in the journal Body and Society.

2. Of course, we also study the ways extension in time and space might be limited by the fundamentally political production-of-culture dynamics that make resistance, apathy, and countermemory an inherent dimension of any collective memory itself (Spillman 1997, 2003), as well as by different generational experiences (Schuman and Scott 1989).

3. This was the thirty-year period of violence involving loyalist and republican paramilitary organizations and the British state over competing claims to the six counties of Northern Ireland. This summary is drawn from Conway 2003, which provides more historical context and analyzes changing themes in the popular memory of the event. The full study (Conway 2005) draws on the complete range of archival and media evidence generated by the event since 1972, as well as interviews and ethnography, and examines variation in meaning making both within and between vernacular and official interpretation and organization.

4. As Gary Fine has pointed out, the distinction here is between emphasizing the body as experienced in the world "from inside out" and viewing the body as an object, from "outside in" (personal communication, June 4, 2004). Many theorists of embodiment challenge social constructionism more generally on the basis that "the embodied self exceeds representation" (Budgeon 2003:51), along the lines of the strong embodiment thesis about collective memory.

5. Unless otherwise noted, quotations are drawn from thirty-one semistructured interviews conducted in 2004 with participants in the annual march, including relatives of victims, former activists, and community workers and leaders. Newton (2003:31), in his critique of one type of embodiment argument, raises the interesting methodological question of "how we can 'interview' the body." Our strategy here was to attend to when and where more intensified and concrete accounts of experiences emerged in lengthy and wide-ranging interviews. Norms of relevance that might downplay reports of physical experience could mean that the frequency of embodied, experiential memory in the commemorative march is understated in this example. Nevertheless, both the variation in our interviews and the frequency of informants' interpretations countering the strong embodiment thesis make us confident that the questions we raise here using this illustration are important ones for future work on embodied memory.

6. See also Kertzer's neglected Ritual, Politics, and Power (1988), which analyzes "the virtues of ambiguity" in ritual (chap. 4).

7. This informant also describes increasing radicalization in the late 1960s and early 1970s: "And I realized ... something significant had changed. These people had seen these things on television of being batoned, very brutally, and that set a spark and the spark was starting to just burn." The perception of media influence is also relevant to our argument here.

8. Global parallels with other subordinate groups were drawn in the 1990s commemorations even though, as one informant observed, "some of these parallels [such as with apartheid] are absolutely fanciful and insulting to the people we draw parallels with." 
9. So, for instance, Kleinman and Kleinman $(1994: 714,720)$ conclude in their important study of embodied memory in the aftermath of China's Cultural Revolution that although victims' "narratives of sickness" linked "bodily memory, biography, and social history," embodied memory was "both personally and socially unavailing," remaining, in Mills's terms, a matter of "personal troubles." On this basis, they criticize theorists who "avoid the question of what processes mediate/ transform the social and the corporal" (p. 710). Recent discussions of cultural trauma also emphasize, against naturalistic and psychologistic understandings, that suffering does not become trauma unless it is culturally and institutionally mediated (Alexander et al. 2004; see also Kenny 1999). However, for a sophisticated analysis of a case in which bodily memory does indeed become "public" dissent, see Skultans 1999 on illness in the interpretation of the Soviet past in Latvia. An interesting and potentially important set of cases for scholars of collective memory to pursue these issues comparatively would be cases of the memory of war (e.g., comparing the various sites of memory discussed in Evans and Lunn 1997, various wars within one country, and the same war in different countries). When does the embodied memory of military service and warinflicted corporeal disability become "public" rather than "personal" memory?

10. Alternatively, however, and against the strong embodiment thesis, inscribed memory may evoke and legitimate embodied memory, as seems to be occurring for some our respondents quoted above. Indeed, against Connerton, embodied memory may be provisional until inscribed. This may account for the importance attached to the Saville Inquiry, which reexamined five hundred eyewitness accounts collected by civil rights associations and set aside by the 1972 Widgery report. As may also be the case in other recent truth commissions and inquiries, inscribed, official history is seen here as giving "a voice back to the victims" (Gibbons 1998:108).

11. Although Bourdieu's (1977:87) discussion of body hexis as a means by which "schemes are able to pass from practice to practice without going through discourse or consciousness" might seem to justify the idea that preconscious inculcation of bodily habit transmits collective memories across generations, he sees this process as important only when "the work of education is not clearly institutionalized as a specific, autonomous practice." Even where cultural production is not differentiated and institutionalized in this way, there is always a dialectical relationship between embodied practice and mental structures or cultural schema (pp. 87-95).

12. Inscribed memory seems even more important if we are concerned with long-lasting collective memories, instances in which collective memories appear to persist over centuries (on the general question of long-lasting cultural forms, see Swidler 1992). An important condition for persistence through generations and through very different political instrumental contexts seems to be fundamentally cultural—semiotic openness (Spillman 2003). Arguably, the spirit possession ritual genre is open in this way, allowing the integration of new historical experiences with the invention of new spirit groups and the acting out of new social issues by existing spirits.

Persistence of collective memories across generations might also be accomplished in the experiential constraints imposed by spatiotemporal organization. This possibility is suggested by Freund's (2001) defense of the "social model" of disability against those who criticize it as too disembodied, although he is not specifically concerned with collective memory issues.

\section{REFERENCES}

Alexander, Jeffrey C. 2004. "Cultural Pragmatics: Social Performance between Ritual and Strategy." Sociological Theory 22(4):527-73.

Alexander, Jeffrey C., Ron Eyerman, Bernhard Giesen, Neil J. Smelser, and Piotr Sztompka. 2004. Cultural Trauma and Collective Identity. Berkeley: University of California Press.

Bourdieu, Pierre. 1977. Outline of a Theory of Practice, translated by R. Nice. Cambridge: Cambridge University Press.

Boyle, Seamus. 1978. Republican News, February 4, p. 6.

Bryan, Dominic. 2000. Orange Parades: The Politics of Ritual. London: Pluto.

Budgeon, Shelley. 2003. "Identity as an Embodied Event." Body and Society 9(1):35-55. 
Burton, Frank. 1978. The Politics of Legitimacy: Struggles of a Belfast Community. London: Routledge.

Collins, Randall. 2004. Interaction Ritual Chains. Princeton, NJ: Princeton University Press.

Connerton, Paul. 1989. How Societies Remember. Cambridge: Cambridge University Press.

Conway, Brian. 2003. "Active Remembering, Selective Forgetting, and Collective Identity: The Case of Bloody Sunday." Identity: An International Journal of Theory and Research 3:305-23.

—. 2005. "Texts, Bodies, and Commemoration: Bloody Sunday (1972) as a Case Study." Ph.D. diss., University of Notre Dame.

Dayan, Daniel and Elihu Katz. 1992. Media Events: The Live Broadcasting of History. Cambridge, MA: Harvard University Press.

Derry Journal. 1973. "Pleas for Dignified Bloody Sunday Commemoration." January 28, p. 1. 1974. Public Notices. January 15.

Evans, Martin and Ken Lunn. 1997. War and Memory in the Twentieth Century. Oxford: Berg.

Flyvbjerg, Bent. 2001. Making Social Science Matter: Why Social Inquiry Fails and How It Can Succeed Again. Cambridge: Cambridge University Press.

Frank, Arthur W. 1991. "For a Sociology of the Body: An Analytical Review." Pp. 36-102 in The Body: Social Process and Cultural Theory, edited by M. Featherstone, M. Hepworth, and B. S. Turner. London: Sage.

Freund, Peter. 2001. "Bodies, Disabilities, and Spaces: The Social Model and Disabling Spatial Organisations." Disability and Society 16:689-706.

Gartner, Joelle. 1998. "Anger at the Heel: The Legacy of Bloody Sunday." Pp. 117-31 in Hidden Truths: Bloody Sunday 1972, edited by T. Ziff. Santa Monica, CA: Smart Art.

Geertz, Clifford. 1973. "Thick Description: Toward an Interpretive Theory of Culture." Pp. 3-30 in The Interpretation of Cultures. New York: Basic Books.

Gibbons, Luke. 1998. "History without the Talking Cure: Bloody Sunday as 'Modern Event."' Pp. 101-9 in Hidden Truths: Bloody Sunday 1972, edited by T. Ziff. Santa Monica, CA: Smart Art.

. 2001. "Where Wolfe Tone's Statue Was Not: Joyce, Monuments, and Memory." Pp. 139-59 in History and Memory in Modern Ireland, edited by I. McBride. Cambridge: Cambridge University Press.

Glassie, Henry. 1982. Passing the Time in Ballymenone: Culture and History of an Ulster Community. Philadelphia: University of Pennsylvania Press.

Goodwin, Charles. 2000. "Action and Embodiment within Situated Human Interaction." Journal of Pragmatics 32:1489-522.

Halton, Eugene. 1992. "The Cultic Roots of Culture.” Pp. 29-63 in Theory of Culture, edited by R. Munch and N. J. Smelser. Berkeley: University of California Press.

Howson, Alexandra. 2004. The Body in Society. Cambridge: Polity.

Igarashi, Yoshikuni. 2000. Bodies of Memory: Narratives of War in Postwar Japanese Culture, 1945-1970. Princeton, NJ: Princeton University Press.

Jarman, Neil. 1997. Material Conflicts: Parades and Visual Displays in Northern Ireland. Oxford: Berg.

Kelleher, W. F. 2003. The Troubles in Ballybogoin: Memory and Identity in Ballybogoin. Ann Arbor: University of Michigan Press.

Kenny, Michael G. 1999. "A Place for Memory: The Interface between Individual and Collective Memory." Comparative Studies in Society and History 41:420-37.

Kertzer, David. 1988. Ritual, Politics, and Power. New Haven, CT: Yale University Press.

Kleinman, Arthur and Joan Kleinman. 1994. "How Bodies Remember: Social Memory and Bodily Experience of Criticism, Resistance, and Delegitimation Following China's Cultural Revolution." New Literary History 25:707-23.

Lee, Sandra S.-J. 2000. "Dys-appearing Tongues and Bodily Memories: The Aging of First-Generation Resident Koreans in Japan." Ethos 28:198-223.

Mead, George H. 1962. Mind, Self, and Society. Vol. 1. Chicago: University of Chicago Press.

Mills, C. Wright. 1959. The Sociological Imagination. London: Oxford University Press. 
Newton, Tim. 2003. "Truly Embodied Sociology: Marrying the Sociological and the Biological?" Sociological Review 51:20-42.

Olick, Jeffrey K. and Joyce Robbins. 1998. “Social Memory Studies: From 'Collective Memory' to Historical Sociology of Mnemonic Practices.” Annual Review of Sociology 24:105-40.

Scheper-Hughes, Nancy and Margaret M. Lock. 1987. "The Mindful Body: A Prolegomenon to Future Work in Medical Anthropology." Medical Anthropology Quarterly, n.s., 1:6-41.

Schumann, Howard and Jacqueline Scott. 1989. "Generations and Collective Memory." American Sociological Review 54:359-81.

Schwartz, Barry. 2005. "The New Gettysburg Address: Fusing History and Memory.” Special issue, "Cultural Sociology and Sociological Publics," edited by M. Jacobs and L. Spillman. Poetics 33:63-79.

Skultans, Vieda. 1999. "Narratives of the Body and History: Illness in Judgment on the Soviet Past." Sociology of Health and Illness 21:310-28.

Smelser, Neil. 2004. "Psychological Trauma and Cultural Trauma." Pp. 31-59 in Cultural Trauma and Collective Identity, edited by J. Alexander et al. Berkeley: University of California Press.

Spillman, Lyn. 1997. Nation and Commemoration: Creating National Identities in the United States and Australia. Cambridge: Cambridge University Press.

- 2003. "When Do Collective Memories Last? Founding Moments in the United States and Australia." Pp. 161-92 in States of Memory: Continuities, Conflicts, and Transformations in National Retrospection, edited by J. K. Olick. Durham, NC: Duke University Press.

Stoller, Paul. 1994. "Embodying Colonial Memories." American Anthropologist, n.s., 96:634-48. -1997. Sensuous Scholarship. Philadelphia: University of Pennsylvania Press.

Sunday World. 1978. LHNIPC, NIO Cuttings Files, Londonderry Civil Rights March. January 29. Linenhall Northern Ireland Political Collection, Belfast.

Swidler, Ann. 1992. "Inequality and American Culture: The Persistence of Voluntarism." Pp. 294314 in Reexamining Democracy: Essays in Honor of Seymour Martin Lipset, edited by G. Marks and L. Diamond. Newbury Park, CA: Sage.

Turner, Bryan S. 1984. The Body and Society: Explorations in Social Theory. Oxford: Blackwell.

- 1991. "Recent Developments in the Theory of the Body." Pp. 1-35 in The Body: Social Process and Cultural Theory, edited by M. Featherstone, M. Hepworth, and B. S. Turner. London: Sage.

Waters, Mary. 1990. Ethnic Options: Choosing Identities in America. Berkeley: University of California Press.

Williams, Simon. 2003. "Marrying the Social and the Biological? A Rejoinder to Newton." Sociological Review 51:550-61.

Witz, Anne and Barbara L. Marshall. 2003. "The Quality of Manhood: Masculinity and Embodiment in the Sociological Tradition." Sociological Review 51:339-56.

Young, Katherine. 2002. "The Memory of the Flesh: The Family Body in Somatic Psychology." Body and Society 8(3):25-47. 
